\title{
Socio-demographic problems of the development of united territorial communities of the Eastern Regions of Ukraine
}

\author{
Boichenko Elina; Vasilchuk Nataly \\ Department of problems of inter-regional cooperation issues \\ Institute of Economic and Legal Studies of the National Academy of Sciences of \\ Ukraine, Kyiv, Ukraine \\ e-mail correspondence: economicaukraina2017@gmail.com
}

\begin{abstract}
Taking into account the comprehensive decentralization reform in Ukraine, which began in 2014 and the ambiguity of the situation in the East of Ukraine, there is an increased interest in the study of decentralization processes in these regions. Since the process of unification of local communities involves, above all, taking into account the interests of the population, the authors decided to consider the socio demographic problems of local communities united by the example of the Donetsk region. The article substantiates the expediency of choosing as an example of the Liman City United Territorial Community. The dynamics of distribution of population by the communities of Donetsk region is presented. The dynamics of changes in the population of the Liman city UTC before and after the merger are analyzed. Revealed changes in the age structure of the population of the community and founded the main causes and consequences of these changes. In addition, it has been found that, contrary to changes in the territorial structure of the country, the existing form of submission of statistical information remains unaltered (statistics are provided in the traditional way, namely, in cities and rayons of the region), which in turn does not allow to trace all social and economic changes and requires an immediate reformatting of statistical forms.
\end{abstract}

Keywords: reproduction, migration, mortality, natural population movement, decentralization, united territorial community

JEL classification: J10, J11, O15

\section{INTRODUCTION}

Considering the process of decentralization and association of territorial communities as a possible key factor in the economic and social development of Ukraine, it is necessary to pay attention to the fact that this process is very tightly overlapping with the existing demographic problems. The deterioration of reproductive processes, as a whole in Ukraine and separately in each region, has become a legacy of newly formed territorial communities. The problem is not only the general reduction of the rural population, but also changes in its structure.

The low fertility rate, high mortality of the working-age population, the search for better living conditions, which in turn contribute to the intensification of labor migration mainly among young people and families with children, cause a decrease in the population, which is accompanied by an increase in the number of people of older 
age groups, that is, its aging. Strengthening of these processes significantly changes the structure of expenditures in the budgets of territorial communities. The increase in the proportion of persons of retirement age in the structure of the population requires an increase in expenditures in the budget of the united territorial communities aimed at their social security. Given the limited financial resources, prerequisites for the proliferation and deepening of poverty in old age are created, and the demographic burden on the able-bodied population increases. In this case, particularly important theoretical and methodological and practical study of the structure and dynamics of socio-demographic trends combined development of local communities and establishing the causes that affect it.

Proceeding from the text above, the purpose of the article is to reflect the sociodemographic problems of the development of the united territorial communities of the Eastern regions of Ukraine.

Based on the aim of the study, the following tasks were set and solved: a) the dynamics of distribution of population by the communities of Donetsk region is investigated; b) the number of the existing population of the Liman city community for years, before and after the association is presented; c) analyzed the structure of the population of the Lima united territorial community in 2015; d) set trends vital Limanskaya city united local community for the period 2009-2015 years; e) the dynamics of migratory flows of the population of the Liman Municipal Joint Territorial Community for the period 2010-2015 is reflected; f) the conclusions are drawn up and the vector of further socio-economic development of the community is outlined.

Exploring the socio-demographic problems of the development of the united territorial communities of the Eastern regions of Ukraine, it should be noted that the vital activity of the united territorial community in Ukraine takes place in the specific historical conditions that have developed in a certain territory and are determined by a system of diverse activities in all spheres of community life; social, political and spiritual.

The development of united territorial communities is possible under the conditions of the existence of a suitable environment, both external and internal, which consists of many components. So, the external environment is formed by the presence of natural geographic, political, legal, economic, social, informational, educational, cultural, religious, ethnic and other space. The components of the internal environment is advisable to consider reproduction, state public health level and quality of life, education, culture, marital status, professional activity and more.

In addition, it should be noted that the process of association of territorial communities in Ukraine began in 2014, against the background of decentralization reform. The transition from centralized to decentralized management involves first and foremost the reform of the administrative-territorial system (ATS), that is, the division of the state's territory into certain parts of it for the purpose of organizing local management, which in turn is carried out by created newly formed administrativeterritorial units of all levels - villages and settlements, districts, cities, and oblasts by public authorities Koliushko, I. \& Tymoshchuk, V. (2005). 
Thus, in this study under the administrative-territorial system is understood the system of the internal territorial structure of the state, the main purpose of which is to form, organize and provide the territorial basis for the implementation of local public authorities, according to which the organization of the functioning of local bodies of state power and local self-government and the development of regions, which contributes to the balanced development of the state as a whole.

Statistical data are also evidenced by changes in the administrative territorial structure of the country. According to official data, the decentralization in Ukraine placed on the site as of December 8, 2017 in Ukraine has created 697 united territorial communities. According to the forecast calculations at the beginning of 2018 as a result of administrative-territorial reform expected formation of about 1,500 wealthy communities. The newly formed united territorial communities will comprise about $15 \%$ of the total number of local government local governments and will live about 3.1 million people. The territory of the now generated united territorial communities in the regions of Ukraine - is about 600 thousand hectares, which makes about 9,5\% of the total area of the country 60 million 362 thousand 800 hectares Current state and use of land resources of Ukraine (2017).

Due to such radical steps, there is a need for systematic tracking of the trends of socio-economic development of communities on the basis of which it will be possible to predict and respond quickly to risks, as well as to develop well-considered operational, strategic decisions on the management of the territory.

\section{RESEARCH METHOD}

The methodological basis of the study is the dialectical method of knowledge, a systematic approach to the study of social and economic phenomena, developments of domestic and foreign scholars on issues of decentralization and united communities. In the article methods of absolute, relative and average values, analysis of the series of dynamics and structural changes (in the analysis of national and regional socioeconomic processes), comparison (in the establishment of violations in community development processes), graphic (in the study of sex-age structure population of communities), visualization (for presentation of results of community development).

Analytical results of the article are based on the use of official statistical information of the State Statistics Service of Ukraine and the Main Department of Statistics in Donetsk region.

In addition, the method of logical generalization (in determining the socioeconomic status of the development of the combined territorial communities), the method of absolute, relative and mean values, the analysis of the series of dynamics and structural changes (in determining the dominant trends in the formation and development of UTC) is used, method economic analysis and synthesis (in determining the content content of socio-economic problems), the method of comparison (with the establishment of violations in the processes of socio-economic development of UTC), the graphical method (for constructing the trend of the number of existing population of the Liman city community before and after the association), the method of visualization 
(to present the results of the structure of the population of the Liman united territorial community in 2015 year, dynamics of migration flows).

\section{RESULT AND DISCUSSION}

At the beginning of 2018 in the Donetsk region were formed 10 united territorial communities, and in five communities elections were scheduled for the end of the year. The population of united territorial community is amounted to 139,0 thousand people $(3,24 \%$ of the total population of the Donetsk region). The distribution of population in the communities is given in Table 1 Official site Decentralization in Ukraine (2017).

According to the results of the study, it can be argued that in almost all communities there was a decrease in the population, despite such a short observation period. Regarding the Cherkasy community, the population growth was not due to its natural growth, and for the registration of internally displaced persons.

Table 1. Dynamics of distribution of population by the communities of Donetsk region in 2015 and 2018

\begin{tabular}{|c|c|c|c|c|c|}
\hline \multirow[b]{2}{*}{ Community } & \multirow{2}{*}{$\begin{array}{l}\text { Year of } \\
\text { creation }\end{array}$} & \multirow{2}{*}{$\begin{array}{l}\text { The population } \\
\text { of the } \\
\text { community } \\
\text { when it was } \\
\text { created }\end{array}$} & \multirow{2}{*}{$\begin{array}{l}\text { The population } \\
\text { of the } \\
\text { community as } \\
\text { of } 1.04 .2018\end{array}$} & \multicolumn{2}{|c|}{ Deviations } \\
\hline & & & & $\begin{array}{c}\text { Absolute } \\
(+/-)\end{array}$ & $\begin{array}{c}\text { Relative } \\
(\%)\end{array}$ \\
\hline Andreevskaya & 29.10 .2017 & 1942 & 2413 & +471 & 24,25 \\
\hline Zvanivska & 29.10.2017 & 3303 & 2576 & -727 & $-22,01$ \\
\hline Illinivska & 18.12 .2016 & 11171 & 9553 & -1618 & $-14,4$ \\
\hline Limanskaya & 25.10 .2015 & 48570 & 43594 & -4976 & $-10,25$ \\
\hline Mykolaiv (city) & 18.12.2016 & 18747 & 17470 & -1277 & $-6,81$ \\
\hline Aleksandrovskaya & 29.04 .2018 & 16147 & 13628 & -2519 & $-15,60$ \\
\hline Siverska (city) & 30.04 .2017 & 15383 & 13962 & -1421 & $-9,24$ \\
\hline Soledarska (city) & 18.12.2016 & 23494 & 20891 & -2603 & $-11,08$ \\
\hline Cherkassy & 25.10 .2015 & 9512 & 11963 & 2451 & 25,77 \\
\hline Shakhivska & 25.10 .2015 & 3065 & 2964 & -101 & $-3,29$ \\
\hline
\end{tabular}

Source: Compiled by the authors according to the sources official site decentralization in Ukraine (2017)

It is important to note that the decrease in the population is occurring almost throughout Ukraine. There are many reasons for this. This is the level and quality of life of the population, the existing level of wages, political instability in the country, the presence of a military conflict in the East, etc. This trend is observed in communities. The consequences of these events are, above all, changes in the age structure of the population communities.

The transformation of the sex-age structure of the population and the narrowed type of it's reproduction cause an increase in the proportion of people over the ablebodied age in the structure of the population of the community, which, in turn, increases the burden on the able-bodied population. For united territorial communities, this may be an obstacle to their development. Identified negative effects cause a chain effect and influence on almost all aspects of life of united the territorial community. For example, 
in the social life of the community, aging affects the composition of the family, the epidemiological situation, needs and types of medical care. In the ebconomic life of the united territorial community, the aging of the population negatively affects, first of all, the formation of community budgets and the definition of social policy directions. In addition, these processes affect the structure of consumption of tangible and intangible benefits, services and savings of the community. In the political life of the aging population, communities can influence the results of elections not only of city authorities, but also of presidential and parliamentary ones, due to the historical, educational, cultural and mental environment in which a generation of older age groups was raised.

It should also be noted that contradicted changes in the territorial structure of the country, the current form of presenting statistical information remains variable, which in turn prevents trace all social and economic change. To date, statistics are provided in the traditional way, namely in the cities and districts of the region. Taking into account the fact that the process of creation of united territorial communities in Ukraine contributed to the change of the administrative-territorial system, there is a need for new forms of statistical information provision. This need is also due to the systematic and incomplete disclosure of statistical information on the official sites of the combined territorial communities and decentralization in Ukraine. The lack of timely response, including the state service of statistics, to changes taking place in the territorial structure of the country, doesn't allow fully trace the dynamics of the processes of development of territorial communities, which complicates not only the formation of scientifically grounded conclusions, but also makes it impossible to predict the indicators of development of UTC.

Proceeding from the foregoing, the coverage of socio-demographic problems of the development of UTC was carried out on the example of the Liman city united territorial community, since this very community completely united the existing Krasnoliman district, that is, became the successor of this territory. The existence of comparable statistical information made public (before and after the merger), makes it possible to analyze the trends that occurred after the reform of the decentralization of power in the area.

In addition, it is necessary to overlook that today, the community chosen as the example, it is the largest in Ukraine. In the long run, with the proper allocation of resources and a clear definition of vectors of economic development, it can reach heights and become an example of the successful implementation of decentralization in the region.

The formation of Liman UTC was dated on November 17, 2015. The reason was the decision of the Krasnoliman City Council "On the Suspension of the Activities of Village and Village Councils", which was eliminated by joining the Krasnoliman City Council. Subsequently, 12 village and settlement councils became part of Krasnolimanskaya UTC. Thus, in the territory of Krasnolimansky district in November 2015 the UTC with the center in the city of regional subordination - Krasny Lyman appeared. Subsequently, according to the Resolution of the Verkhovna Rada of Ukraine dated February 4, 2016, the Krasny Liman of the Donetsk Region was renamed into the 
city of Liman, and the UTC in the Liman City Municipal Unified Territorial Community, which included 40 settlements Official site Decentralization in Ukraine (2017).

The most important problem of the development of almost all the united territorial communities of the East of Ukraine is the rapid reduction of the population. It should be noted that under the reproduction of the population of the united territorial communities, the authors understand the totality of three types of population movement: natural (continuous restoration during the change of generations), spatial (migration) and social (social mobility), expressing the decisive line of the entire population movement, its inextricable connection with the process of reproduction and development of society as a whole. Each component of reproduction of the population (population, settlement, sex-age, national, confessional, marriage and family structures) characterizes the demographic processes that occur in the community.

So long-term changes in the age structure of the population could become irreversible and significantly change the structure of its reproduction. In this case, research of the problems of reproduction of the population of the united territorial communities becomes of special importance. This problem is not an exception for the Liman City UTC (Figure 1 and Figure 2).

The dynamics of the change in the size of the existing population of the Liman City Integrated Territorial Community suggests that there is a long-term trend of its natural decline.

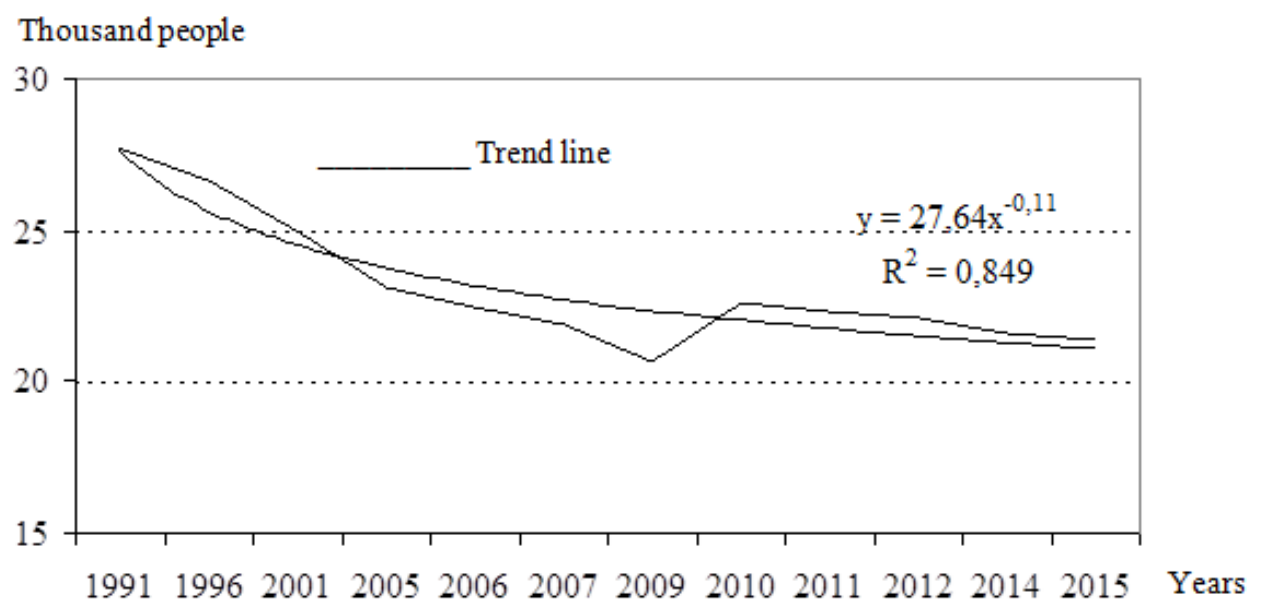

Figure 1. Dynamics of available population Limanskaya united territorial community before and after the merger.

Source: $\quad$ Compiled by the authors according to the sources population (1990-2014). State Statistics Service of Ukraine.

So, from 1991 to the time of the formation of UTC and after the merger, the trend remains unchanged. So, in early 2016, the population declined by almost a quarter, from 27.7 thousand people to 21.38 thousand people.by $23 \%$. According to the results of the obtained trend model, it can be concluded that on average, the population of the community annually decreased by almost 500 people. As noted, the negative social and demographic processes by the way, causing changes in the age structure of the population (Fig. 2). 


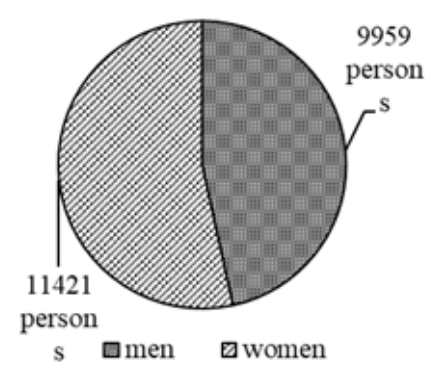

for 1,000 women account 872 men

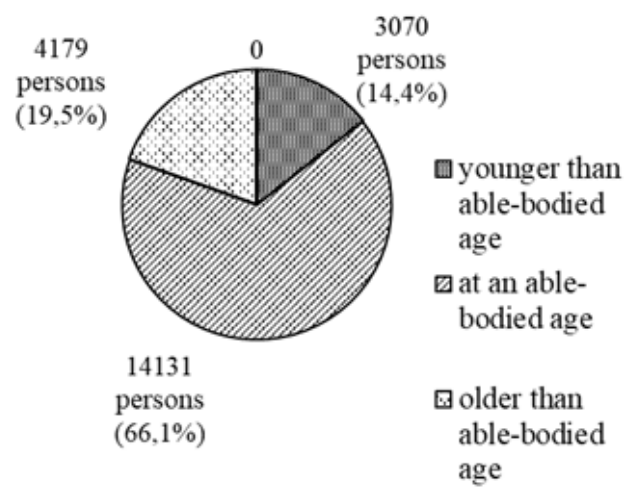

Figure 2. The structure of the population of Liman united territorial community in 2015.

Source: Compiled by the authors according to the sources State Statistics Service of Ukraine population (1990-2014), demographic yearbook "Population of Ukraine for 2015" (2016)

It should be noted that the demographic aging of the UTC population of the East of Ukraine is conditioned by an increase in the proportion of older people in the total population (aging from above), the reasons for which are the changes in the nature of its reproduction. Recall that the "bottom-aging" occurs by gradually reducing the number of children due to fertility decline, it is not a characteristic of the eastern territories.

Changes in the age structure of the population of the Liman city united territorial community are marked by a steady increase in the proportion of older people in the context of a significant reduction in the proportion of children in total. So, in 2015, the demographic burden on the able-bodied population (15-64 years) by older people was $295 \%$ and that of the working age $-218 \%$ demographic yearbook "Population of Ukraine for 2015" (2016). Therefore, given the current dynamics is likely that in the future the community will be narrowed characteristic type of population reproduction over a long period will increase the negative effects such as depopulation and aging population.

Furthermore, it should be noted that the aging population deepens gender asymmetry, which appears to increase the proportion of women in both working and non working age. The current situation exacerbates the reduction in men's life expectancy compared to women. High mortality and low life expectancy of men. This led to the fact that in Ukraine men (life expectancy of men 66.3 years) live almost ten years less than women (76.2 years) the statistical bulletin "Birth rate tables of the expected life expectancy" (2017). The increase in the mortality rate of men of working age in the Eastern regions is the result of the complex action of many processes. In particular, it may be due to the fact that men are engaged in activities that are characterized by a high risk of injury and mortality. So, for the community rapidly aging population dynamics characterized by a continued increase in women, especially retirement and retirement age, which makes special needs to ensure women's life. Special needs are manifested in the impossibility of fulfilling a certain household work by women. In turn, this requires additional attention and assistance to this category of people on the side of the municipal authorities of the united territorial communities.

There is no doubt that the more the age structure of the population of ablebodied youth, the easier it is to fulfill the task of providing the elderly. Thus, particular concern is the reduction in the number of young people, due to which, first of all, there 
is a replenishment of labor resources. The low fertility rate and its sustainability over a long period of time significantly affect the natural reproduction of the population of the Liman City Integrated Territorial Community (Table 2).

Table 2. Dynamics of the natural movement of the population of the Liman city united territorial community

\begin{tabular}{lrr}
\hline Indexes & $\mathbf{2 0 0 9}$ & $\mathbf{2 0 1 5}$ \\
\hline Number of births, persons & 233 & 172 \\
Number of deceased persons & 479 & 435 \\
Natural increase (decrease) of population, persons & -246 & -263 \\
Fertility rate (per 1,000 population) & 11,3 & 8,0 \\
Mortality rate (per 1,000 population) & 23,2 & 20,35 \\
Natural increase (decrease) population (per 1000 population) & $-11,9$ & $-12,4$ \\
\hline
\end{tabular}

Source: Compiled by the authors according to sources demographic yearbook "Population of Ukraine for 2015" (2016), statistical bulletin "Natural Movement of Population for 2016" (2017)

It is proved that the birth rate as any other demographic process reflects the laws of reproduction of social life. The structure and the natural movement of the population depends primarily on decisions made by households. So on the decision to have one or more children, and vice versa, the "childfree family" affects household incomes, their material and living conditions, and the development of the social infrastructure of the territory. Also, this level is conditioned by the current social policy of the state, which concerns the support of families with children, the level of health care, the existing system of education and culture, etc.

Statistical observation suggests that in recent years Limanskaya city united territorial community was a significant decrease in the number of births, from 233 persons in 2009 to 172 people in 2015, nearly 26,2\% (61 person); the total fertility rate decreased accordingly from $11.3 \%$ o to $8.0 \%$ demographic yearbook "Population of Ukraine for 2015" (2016), statistical bulletin "Natural Movement of Population for 2016" (2017), while the mortality rate is rising.

Another negative processes that affect the population structure Limanskaya city united territorial community, is a high mortality rate, especially of working age, which instead trends to increase the statistical bulletin "Birth rate tables of the expected life expectancy" (2017).

A comparative analysis of the sex-age structure of mortality suggests that high rates are recorded among the able-bodied population (mortality in the age group from 20 to 59 years is $35 \%$, at the age of 19 years-6,8\%) the statistical bulletin "Birth rate tables of the expected life expectancy" (2017), while in European countries - this older age group. It should also be noted that in this age range, male mortality significantly exceeds this figure in women $(78,4: 21,6 \%$, respectively), which results in the development of disproportions between the number of men and women in older age groups.

Investigating socio-demographic problems of the development of the united territorial communities of Ukraine's east, attention should be paid to such phenomenon as migration of population (Fig. 3). 

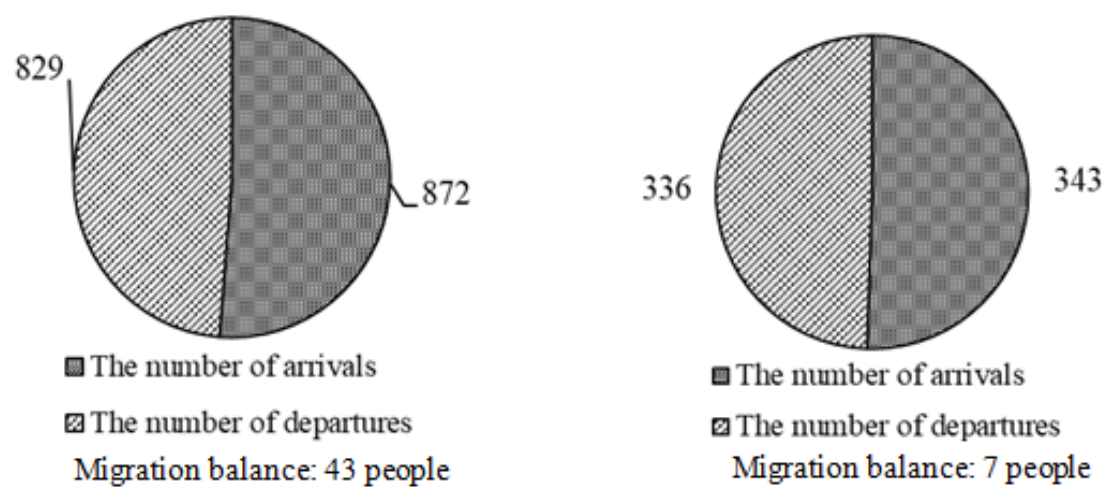

Figure 3. The dynamics of migratory flows of the population of the Liman city united territorial community in 2010 and 2015.

Source: The authors compiled according to sources demographic yearbook "Population of Ukraine for $2015 "(2016)$,

The impact of migration on the demographic situation is ambiguous. Migration processes of the population of the community can actively and quickly influence the reduction or increase of the population, changing its gender and age structure. It is established that the migration activity of the population is formed according to certain laws. The first one that forms a positive balance of migration, which indicates the attractiveness of the united territorial community for life. The second one, which characterizes the negative balance, shows that there are both social and economic problems in the area.

The analysis of the migration structure of the population of the Liman City UTC shows that in recent years there have been no significant changes in the migration flows of the population. Thus, according to the data released by the State Statistics Service of Ukraine, it turns out that there is no loss of population due to migration. However, it should be noted that the State Statistics captures only a tiny fraction of migrants which receives data from the police.

Given that the institution of "residence" in Ukraine was canceled and replaced by the place of registration of residence or stay, it turns out that the presence of the place of registration for employment is not mandatory. These events created the conditions for activation of human population movements, especially youth captured. Note that these flows of labor migration are within Ukraine, and the overall change in the population of the country is not affected. The vector of these streams is aimed at cities where there is a demand for labor. Also, the priority for internal migrants are those settlements where the average salary of workers is higher than the average in Ukraine.

The analysis of the dynamics of the migration processes of Donetsk region according to the age structure of the population shows that the bulk of the participants in these processes falls on the able-bodied part of the population. The intensity of migration processes of people of different ages is not the same. The most mobile group was mostly youth aged 15 to $24(48,48 \%$ of the total number of migrants state Statistics Service of Ukraine population (1990-2014), demographic yearbook "Population of Ukraine for 2015" (2016) just when the school ends and plans for vocational education or employment. However, one should also take into account the fact that migration 
processes are reflected not only in the size of the population, but also in its gender-age structure. Thus, it can be argued that the young and competitive population of the Liman City United Territorial Community participates in these flows of labor migration, being registered in the community.

Interstate migration also influences changes in the population of both Ukraine and the Liman city united territorial community. The problems of population accounting participating in interstate labor migration do not allow to create a reliable model of these displacements, as well as to determine the consequences of the impact of these flows on the reproduction of the social life of the community.

In the context of the study of UTC of the Eastern regions, it should be noted that the high migration activity of the population is due to the consequences of the ATO. So, the aggravation of the situation in the East of the country can lead to a new wave of forced migration of the population. In connection with the resettlement of part of the inhabitants of the affected areas, the average population density has decreased by $20 \%$, state Statistics Service of Ukraine population (1990-2014), demographic yearbook "Population of Ukraine for 2015" (2016), statistical collection "The number of available population of Ukraine as of January 1, 2017" (2017), which is critical given the prospects for restoring the potential of settlements in the Donbass. Separate monofunctional cities are on the verge of irreversible degradation due to the closure of city-based enterprises. The high proportion of settlements in the settlement structure of these areas against the background of much of the population losses due to internal displacement complicates their future recovery Gorbulin VP., Vlasyuk AS., Libanova EM. \& Lyashenko AM. Donbass and Crimea: the price of return (2015).

So, the proximity of the ATO from the city of the location of the Liman Municipal Unified Territorial community increases the risk of activating the labor movements of its inhabitants, which can be assessed as very high.

Taking into account the prospects for the development of the Liman City Territorial community as reflected in its development strategy, in particular, the development of an industrial park, the creation of conditions for investors, for the development of business, tourism, the creation of recreation areas and the formation of a positive image of the community, with a competent allocation of resources and a clear determining vectors of economic development community can reach the heights and become a model of successful implementation of decentralization in the Eastern region.

\section{CONCLUSIONS AND RECOMMENDATIONS}

\section{Conclusions}

Thus, summing up the results of the study, it came to the conclusion that the vital activity of the united territorial community proceeds in the specific historical conditions that have developed in a certain territory. It is determined by various system activities in all areas of community life: economic, social, political and spiritual.

The major problem of almost all local communities united East Ukraine is the rapid population decline. The dynamics of the size of the existing population of the Liman city united territorial community suggests that there is a long-term tendency for 
its natural decline, as well as the fact that negative socio-demographic processes affect changes in the age structure of the population.

It was proved that the transformation of the sex-age structure of the population of the Liman city united territorial community and the narrowed type of its reproduction leads to an increase in the proportion of people over the working age in the structure of the population of the community, which, in turn, increases the burden on the ablebodied population.

Considering the dynamics and structure of migration flows, set the probability narrowed type reproduction of the population over a long period in the future of the community. Outlined the consequences of this situation, including the depopulation and aging population.

Taking into account the aforementioned, it was stated that special attention and analysis is required for the issues of socio-economic consequences of aging of the population, in particular, the impact of these processes on production, consumption, health care, social assistance, investment, and, in turn, on the general contemporary socio-economic conditions characterized by an increase in the burden on the ablebodied population.

In addition, the need to focus on the study of the peculiarities of demographic processses has proved necessary, since the latter are characterized by persistence and inertia which leads to irreversible changes in the economy and politics. So long-term changes in the age structure of the population can significantly change the structure of its reproduction.

\section{Recommendations}

According to the authors, the solution of socio-demographic problems of the combined territorial communities is possible, first of all, due to the improvement of the quality of life of the inhabitants. Thus, the priority should be to ensure stable employment due to the economic development of these areas, the introduction of new technologies (such as solar and wind power, etc.), new construction and restoration of the existing social, transport, information and so on. infrastructure. It is also necessary to ensure an appropriate level of secondary education for adolescents. The fact that the state grants rural youth benefits in admission to higher educational institutions is a recognition that it is unable to provide the proper quality of education that would be sufficient for entry into budget places at universities.

\section{REFERENCES}

Koliushko, I. \& Tymoshchuk V. (2005). Adminterreforma. Journal Partners. No 11. 2005. [Electronic resource]. Access mode: URL http://www.cpp.org.ua/partners (23.01.2018).

Current state and use of land resources of Ukraine. [Electronic resource]. Structure of land resources of Ukraine. Access mode: URL http://geoknigi.com/book_view.php?id=1109 (27.01.2018).

Official site Decentralization in Ukraine. Formed communities. [Electronic resource]. Access mode: URL https://gromada.info/region/ (27.01.2018). 
State Statistics Service of Ukraine. Population (1990-2014). [Electronic resource]. Access mode: URL http://www.ukrstat.gov.ua/operativ/operativ2007/ ds/nas_rik/nas_u/nas_rik_u.html (30.01.2018).

State Statistics Committee of Ukraine. Demographic yearbook "Population of Ukraine for 2015" (2016) - 120 p.

State Statistics Committee of Ukraine. The statistical bulletin "Birth rate tables of the expected life expectancy" (2017) - 167 p.

State Statistics Committee of Ukraine. Statistical Bulletin "Natural Movement of Population for 2016" (2017). - 57 p.

State Statistics Committee of Ukraine. Statistical collection "The number of available population of Ukraine as of January 1, (2017) - 83 p.

Gorbulin, VP., Vlasyuk, AS., Libanova, EM. \& Lyashenko, AM. (2015). Donbass and Crimea: the price of return: [monograph] NISS, (2015). - 474 p. 